\title{
Narrative Métissage as an Innovative Engagement Practice
}

\author{
Kathy Bishop, Catherine Etmanski, M. Beth Page, Brian Dominguez, \\ Cheryl Heykoop
}

\begin{abstract}
Métissage is a creative method that can be used for engaging people in research, learning, teaching, and community or organizational development. As five authors, we offer a window into our diverse experiences with métissage, providing a theoretical overview, a practical description of insights and processes when facilitating métissage workshops, some key lessons learned, and an example of a simple woven narrative of our experiences with métissage.
\end{abstract}

KEYWORDS métissage, storytelling, engagement, arts-based method

\begin{abstract}
Qualitative research, in particular narrative, is all about context and relationships. However, how we think about those relationships and the subsequent forms of analysis and interpretation need to be interrogated. We currently deconstruct lived experiences into parts and then look for relationships. What would it mean to read a life outside narrative, to let the network of relationships construct the narrative? This would radically alter narrative by disrupting the categories of subject/object, time/space, past/present/ future, and body/mind/spirit.
\end{abstract} (Hendry, 2007, p. 492)

In response to Hendry's (2007) question, "What would it mean to [...] let the network of relationships construct the narrative?", this paper's purpose is to describe one method offering the potential for doing just that. Métissage, as will be described below, is a creative method used for engaging people in research, learning, teaching, and community or organizational development. As authors (Kathy, Catherine, Beth, Brian, and Cheryl), we have facilitated, participated in, and observed métissage in classrooms, during conferences, in virtual spaces, in meetings, in connection with other University or community-based events, and as research. Some of us have facilitated together in different team configurations, and some of us have facilitated individually. In this paper, we offer readers a window into our diverse experiences with métissage.

We begin by providing a theoretical overview, followed by a practical description of the processes and insights we have come to understand are useful when facilitating métissage workshops. These include setting the stage, selecting the writing prompt, refining the processes of writing, editing, sharing stories, creating the conditions for listening and dialogue, 
recognizing the impact on listeners, and closing the workshop. Following this synopsis, we offer a few key lessons we have learned through experimentation that have served to refine our individual and collective practice. Finally, to illustrate métissage in action, we offer an example of a simple woven narrative of our experiences with métissage, drawn from our work in different contexts.

\section{Theoretical Foundations of Métissage}

The theory and practice of métissage has gained momentum in Canada over the past decade, primarily through the work of Cynthia Chambers, Erica Hasebe-Ludt, Carl Leggo, and Anita Sinner (see Chambers et al., 2008; Hasebe-Ludt, Chambers, \& Leggo, 2009). It has expanded at the University of Victoria (UVic) through the work of Wanda Hurren, Antoinette Oberg, Kathy Sanford, and Sheila Simpkins, among others. Simpkins employed métissage in her UVic doctoral work to promote peaceful dialogue between Kurdish and Arab students in Kurdistan, Northern Iraq (Simpkins, 2012) and introduced this method to Catherine in 2009. Since then, we have expanded the use of this simple, yet surprisingly powerful method through our work at Royal Roads University (where four of the five authors teach and one is a doctoral student).

As Etmanski, Weigler, and Wong Sneddon (2013) have described, by its very nature, métissage defies categorization and concrete definition. The root of métissage - métis, or $\mathrm{M} \tilde{\eta} \tau \iota \varsigma$, comes from the Greek Titaness and wife of Zeus, who was known for her wisdom, skill, and powers of transformation (Chambers et al., 2008). The root of métissage-métis -is derived from the Latin word mixtus or mixticius meaning mixed. Historically, métissage referred to weaving together cloth of two different fibers (Chambers et al., 2008; HasebeLudt, Chambers, Leggo, \& Sinner, 2013). As a method of creative engagement, it is "a way of merging and blurring genres, texts and identities; an active literary stance, political strategy and pedagogical praxis" (Chambers, Donald, \& Hasebe-Ludt, 2002, para. 1). Métissage draws from the traditions of life writing, storytelling, theatre and - symbolically-from the art of weaving or braiding (Chambers et al., 2008; Etmanski et al., 2013). Through the sharing of stories, it also provides an opportunity to claim and reclaim multiple identities, as well as explore liminal or in-between spaces (Chawla \& Rodriguez, 2011) and contradictory ways of being, knowing, thinking, doing, and relating. As Nigerian author Chimamanda Ngozi Adichie (2009) stated, "There is danger in a single story. The single story creates stereotypes, and the problem with stereotypes is not that they are untrue, but that they are incomplete. They make one story become the only story" (13:05). As such, through the practice of weaving together multiple stories, métissage celebrates non-linearity and disruption while finding common threads across stories, which serves to honour both unity and diversity in the individual and the collective.

Métissage can be understood as an arts-based method insofar as writing is, as Margaret Atwood claimed, one of the most accessible art forms: "There's one characteristic that sets writing apart from most of the other arts-its apparent democracy, by which I mean its availability to almost everyone as a medium of expression" (Atwood, 2002, as cited in Chambers, Hasebe-Ludt, Leggo, \& Sinner, 2012, p. xx). Beyond its storytelling component, métissage is particularly artistic when authors take the time to craft and refine their narratives 
and attend to the aesthetic as they move beyond the catharsis of personal writing. Therefore, as with any art form, métissage has permission to be beautiful and meaningful for its own sake. As a result of this storytelling and aesthetic dimension, métissage presents a new possible means for researchers to represent findings, either verbally, written, or in other artistic forms (e.g. music, dance, silence). It can also enable different ways of knowing. In particular, it can be understood as an "expressive way of knowing" (Davis-Manigaulte, Yorks, \& Kasl, 2006), which is similar to Heron's (1992) presentational knowing. In addition to valuing the aesthetic for its own sake, this way of knowing has a useful purpose as well, insofar as it relates to the educational (learning and teaching) value of métissage which can happen,

when conceptual processes interact with imagination and intuition so as to enable learners to perceive patterns. Presentational ways of knowing include engagement with music, all the plastic arts, dance, movement, and mime, as well as all forms of myth, fable, allegory, story, and drama. (Davis-Manigaulte et al., 2006, p. 27)

As such, métissage can be employed as a method for engaging people in a heart-centered, holistic approach to research, learning and teaching, and community or organizational development, among other practices.

As a research practice that is part auto-ethnography and part performance, métissage resists the paradigmatic discourse of positivist research which seeks to dissect parts and remain objective and dispassionate. Positivists reject "emotional intimacy, verisimilitude, shared experience, narrative truth, the figurative and self-reflective use of language, the use of the scenic method, multiple points of view, realistic dialogue, multiple voices, treating facts as social constructions and minimal theory" (Denzin, 1997, p. 253). In contrast, poststructuralists and interpretive ethnographers hold different epistemological models of truth and, therefore, draw from different methods of inquiry. Hayes and Yorks (2007) noted that,

because the arts have the potential for bringing into consciousness tacit, prelinguistic, preconscious knowing (Yorks \& Kasl, 2006) and creating empathic connection among people with diverse and contradictory experiences, they are a powerful medium for fostering critical subjectivity and critical intersubjectivity. (p. 93)

It is this critical subjectivity and intersubjectivity that offers possibilities in answer to Hendry's (2007) question, "What would it mean to read a life outside narrative, to let the network of relationships construct the narrative?” (p. 492). Métissage creates a space for critical reflection on the self as well as intersubjective knowing of self in relationship. As such, métissage becomes more than a method; it can also lead to a relational way of being in and perceiving the world.

Métissage does not seek to "Deconstruct [the narrative(s) of] lived experiences" (Hendry, 2007, p. 492); instead, as an artistic practice, it creates a generative and liberating learning space that assists people in seeing past the psychological, social, and culturally imposed boundaries 
of their life worlds (Hayes \& York, 2007, p. 91). Furthermore, as a practice in which people can come together and hear multiple and different viewpoints, experiences, and realities, it has the "ability to transform" (Chambers et al., 2008, p. 141) by generating a space that allows for both individual stories and shared experiences to emerge. This can serve to garner new understandings and potential actions that can lead to individual and/or collective change. In this way, "the arts are not [always] an end in themselves but [can also be] an entryway for empowering people to author their own community intervention" (Hayes \& York, 2007, p. 91). As an innovative practice, métissage can enable a change intervention by "tapping into experiential knowing to bridge barriers and join people together in community" (p. 95) and therefore creates both an event and artifact.

Given this method challenges positivism and celebrates ways of knowing through story, several Indigenous and Métis scholars have contributed to the scholarship and practice of métissage. For example, métissage has been described as a decolonizing research sensibility (Donald, 2012), an interpretive Indigenous approach (Lowan-Trudeau 2012), and a Métis manifesto (Kelly, 2012). Although métissage is not solely an Indigenous or Métis practice, as non-Indigenous scholars, we are mindful to acknowledge how the French word métissage (referring to people of mixed ethnicity) has given rise to the cultural group, Métis. We also acknowledge the ongoing effects of colonization, including how racism continues to impact Métis and Indigenous communities. Once when Kathy was facilitating, a participant suggested we consult with Elders about how to describe this practice, which we did prior to writing this article. The advice we received was to clearly differentiate between Métis culture, which is not ours to describe, and the practice of métissage as an arts-based engagement method, which we have described here.

In a tangible sense then, the practice of narrative métissage invites the authoring of individual narratives-personal stories, anecdotes, reflections, poetry, and so on-and then interweaves the individual's narratives with those written by others. As Stauffer (2014) described, narrative data might include letters, written stories, and journals, to name but a few examples. When presented in written form, this narrative data can be woven together with theory, poetry, photographs, and more. When performed orally, narrative métissage can be similar to Readers' Theatre, where people read openly from their scripts, with minimal attention to staging or costumes — though these too are welcome. Projected still images, video, and other creative possibilities may complement the reading as well (Etmanski et al., 2013, p. 126). Through this weaving or braiding of narratives, a single text with multiple authors is generated, often to be read out loud.

As authors, our practice has also been informed by narrative inquiry (Page, 2016). Like narrative inquiry, narrative métissage privileges the teller's experience and uplifts participants as the experts in their experiences (Josselson, 1995). Stauffer (2014) addressed three theoretical strands of narrative inquiry, which are relevant here. These included the work of Jerome Bruner, who described narrative as a uniquely human approach to knowing. Specifically, Bruner (as cited in Stauffer, 2014) suggested, "Narrative forms of thought have to do with ways in which we make sense of lived time, deal with the ambiguities of daily life, and construct our 
conceptions of ourselves" (p. 166). The second strand followed the work of Clandinin and Connelly (2000), and stemmed from the focus on experience documented by John Dewey. In their view, narrative was both method and phenomenon (Clandinin \& Connelly, 2000). According to Stauffer (2014), Clandinin and Connelly sought "to understand how people use story as a means of interpreting experience, how they construct knowledge and meaning from their experiences, and how people live and relive, and tell and retell, their stories" ( $\mathrm{p}$. 170). Finally, the third strand, based on the work of Bakhtin, came from literary nonfiction and, through storytelling, sought to raise questions to facilitate conversation about current experiences or issues of importance (Page, 2016, p. 52).

These three strands offer insight into the diverse and contested terrain of narrative inquiry as a research methodology (Clandinin, 2013; Connelly \& Clandinin, 1990; Page, 2016; Polkinghorne, 1995; Stauffer, 2014). For the purposes of understanding narrative métissage, we appreciate the perspective of Jerome Bruner (1991), who suggested, "The central concern is not how narrative as text is constructed, but rather how it operates as an instrument of mind in the construction of reality" (pp. 5-6). This approach to narrative allows participants to share their own stories and listen to those of others, without questioning their inherent accuracy or validity. In so doing, narrative métissage serves as a process of uncovering and co-constructing knowledge about self, other/others, and the world (Etmanski et al., 2013). As such, the ontology of métissage embraces the messiness of reality and narrative complexity of human life.

\section{Practical Applications of Métissage}

Having provided an overview of the theory behind métissage, we now turn to the practice itself. In the sections below, we offer insights from our experience as facilitators in a range of settings. However, since this is a creative method, we encourage you to adapt these guidelines in your own contexts. We offer these as suggestions based on what has worked well for us, but these ought not be considered directions. Rather, they are invitations with which you can experiment and play.

\section{Setting the stage}

As facilitators, we take the time to set the stage so participants have enough information to feel comfortable, or at least not resistant, to engage in the activity. We do this by offering a brief explanation of what métissage is along with its historical roots. Grounded in the theory above, we describe why it can be a powerful tool in general, for example, because it celebrates disruptions, recognizes the messiness of life and nonlinear realities, highlights universal threads across stories, respects the individual and the collective, and provides opportunities to claim and/or reclaim multiple identities, liminal spaces, and sometimes contradictory ways of being, knowing, thinking, and doing. We also make links with the specific context or topic of the workshop.

At the outset, we tend to emphasize two key points underlying the process: firstly, that this practice is an invitation and, secondly, that we are co-creating the space. As facilitators, we 
express that no one should feel forced to participate in an activity. We also clarify that although we invite people to decide how they will show up, this does not mean we are suggesting they opt-out. Rather, the way they opt-in can take many forms, such as taking on the role of an active observer who can contribute unique insights into the process. Furthermore, since as facilitators we agree we cannot assume what a safe space may look like for all participants (Etmanski, 2014), we ask participants to co-create a brave space (Arao \& Clemens, 2013) with us. This acknowledges that at times we may feel uncomfortable or choose to take risks, or that we may enable spaces of grace where we accept people however they show up, trusting the process will deepen our understandings and connections.

At this point of setting the stage, we then give an overview of the process which will involve writing, editing, weaving, sharing, listening, dialoguing, and closing the session. We also find it is effective to model by letting participants listen to and experience a métissage we have written ourselves. This is not a necessary way to proceed. At times, we have also chosen to write our métissage along with the participants. However, we have found that writing and then reading aloud our own métissage prior to the workshop is a way of connecting more deeply as facilitators. For example, we have found we often learn something new about our colleagues, whether we have just met or have known one other for years. Also, by creating our own métissage prior, we have found as facilitators that we are able to maintain a strong focus on facilitating, rather than participating and facilitating which may divide our attention during the session. If you are facilitating a métissage session on your own and would like to provide an example, you may also choose to offer the one we created about the power of métissage written individually and then woven together-which we have shared at the end of this article. Alternatively, you may decide to get creative, as Catherine did, by weaving together fictional characters' narratives excerpted from novels. To begin though, we always offer prompts to support individuals in writing their stories. This serves to both focus their writing and offer inspiration.

\section{Selecting the writing prompt}

In our work as facilitators, we have come to understand the importance of offering a juicy prompt. Any kind of writing prompt is, of course, possible to use; however, we have found that an ambiguous prompt with multiple, even potentially contradictory interpretations, can sometimes stimulate more creative responses. For example, when Catherine was first introduced to narrative métissage by her students in 2009, they offered the writing prompt "standing outside". Used with permission, this prompt has proven to be productive for us in a range of settings. Other prompts we have experienced include "on the edge" (or at times, "out on the edge") and "the words I didn't speak" (with thanks to feminist arts-based educator, Darlene Clover). We also adapt to the particular context and make use of additional prompts in the moment, depending on the discussion in the room. For example, at a conference titled, "Narrative Matters", Kathy, Catherine, and Brian simply used the prompt "Why does narrative matter?" For this very article, we utilized "the power of métissage" as a prompt, the results of which readers will see below. 
Generally speaking, a prompt serves to unite participants around a particular theme. Using the same writing prompt for different people can help to reveal both similarities and differences in the room-not only in terms of people's experiences, but also in relation to how they interpret the prompt, as well as in their writing styles. That said, there have been times when different people have written in response to different prompts, and this too can yield some interesting results. However, our preference has evolved to group people around the same prompt. At times, we will offer a variety of prompts, enabling participants to choose the one that resonates most for them. After this, we can group participants according to the prompt they have selected.

\section{Refining the process of writing}

There are a range of possibilities for writing narratives that ultimately become woven into a métissage. When our intention was to create a presentation of an already woven narrative métissage, it has been helpful to agree upon and send out the prompt in advance, and then spend some individual time writing before reading the métissage out loud together. This way, participants can edit their words in advance of sharing them with others. In the context of facilitating shorter workshops (i.e., less than three hours), we have found that setting a limit of approximately 300 words or fewer has been helpful, depending on how many people are participating.

When we have conducted a workshop where the writing occurred on the spot, we have found it helpful to explain the concept of free writing. As mentioned above, narratives could include stories, poems, letters, and more-and we have even experienced one person include a physical gesture, and another break into song. To access these creative narrative possibilities, the free writing process we suggest entails writing, non-stop, without filtering one's thoughts, for a timed period. To set the tone and atmosphere for free writing, we often start with a poem or quote, such as the one Cheryl likes to use, by the late Ojibway Elder, Richard Wagamese (2016):

\footnotetext{
Write spontaneously every day for fifteen minutes. First, get settled. Breathe.

Big, deep, full breaths, taken slowly. Clear your mind of words. Be wordless.

Then, open your eyes and write whatever comes out of you, and keep writing without taking your hands from the paper or the keyboard for fifteen minutes. Don't worry about punctuation or spelling. Just write. Every day. Fifteen minutes. Regardless. Watch what happens to your level of craft when you work on a project. Why? Because stories live in our bodies and we need to feel our fingers moving in the process of creation every day. Your hands are your interpretive tools. They bring your spirit out in words and language. (p. 68)
}

During this free writing period, participants' perceptions of time can shift, so they often do not need long to get a few thoughts out on paper. In an hour and a half to two-hour workshop, we have found that five minutes is plenty of time to come up with a sufficient narrative to create a shared experience of métissage. Again, we encourage people to flow with their 
writing, and just keep writing until the timed period is over. To avoid self-censorship during this writing period, we let them know in advance that they will have an opportunity to edit out sections prior to sharing their narratives with others. We invite them to make an intentional choice about whether they would like to keep their narratives light-hearted, or to delve more deeply into their personal experiences.

\section{Refining the process of editing}

Following this free writing period, we invite participants to re-read for themselves what they have written and decide which of this is meant for their own eyes and ears only, and which sections they would feel comfortable sharing out loud. As they will ultimately be weaving their narratives with those of others, as they are editing, they need to find two or three breaks where they could temporarily pause the reading of their narratives to enable other people to interweave their own. As such, we encourage participants to look for natural breaks in their narratives. These sections do not need to be uniform in length, nor does the anecdote or story need to be neatly wrapped up inside a segment. In fact, some powerful segments are only a few words long, or contain no words at all, or are incomplete stories that leave the audience in suspense until the next time that speaker comes around in the braided text.

In a workshop setting, participants can spend another five minutes or so completing this individual editing task to get their narratives ready to share with others. The point here is that we are not seeking perfection. We encourage people to only share what they feel comfortable sharing and not get too attached to the meticulous process of crafting their words. If they choose to publish their métissage at a later date, they will likely need to spend more time editing, but for a short workshop we recognize the readings will likely be a fleeting, albeit powerful, moment in time. If they are writing their narratives outside of a workshop setting, the facilitators can either ask participants to identify the speaking breaks, or can look for breaks themselves.

\section{Refining the process of weaving}

Once the narratives are complete, the usual next step in a workshop setting is to work in small groups to share stories, weave them together, and create a woven métissage. There are ways to streamline this part of the process if you are short on time; however, these small group conversations can provide rich opportunities for dialogue and deepening relationships. As such, we have found it helpful to allow a longer period (e.g., 15 to 20 minutes) to complete this weaving and some participants always ask for more.

Since this is a creative method and we like encouraging creativity in how people come together, we feel ambivalent about giving concrete directions at this stage. The extent to which we lay out the steps, or let them emerge, is normally dependent on how many participants there are and how much time is available during the workshop. It also depends whether we have modelled a narrative métissage in advance. We know modelling can limit creativity, but it also provides some reassurance when people are at the weaving stage since they have an impression of an approach they could adopt.

As general guidelines, we find it helpful to suggest a structure and then ensure they know

Engaged Scholar Journal: Community-Engaged Research, Teaching, and Learning 
that there is flexibility within that structure. Often, we suggest that each person read their narrative in its entirety without stopping at the identified breaks. Once they have heard each person's complete narrative, they will see where the points of connection are and which sections from each person they might want to juxtapose by placing them next to one another in the reading. In this way, they can decide who goes first, who goes next, and so on until all group members have read all sections of their narratives.

A more linear way we sometimes suggest is simply by identifying Person A, Person B, and Person $\mathrm{C}$ in a group of three, for example. If they do this, and they each have their narratives divided into three sections, they can weave their stories together simply by reading in order: Section 1, Person A-B-C; Section 2, Person A-B-C; Section 3, Person A-B-C. However, after they have heard one another, they will sometimes wish to change this order based on the content, or based on the realization that someone has divided a narrative into four or five sections instead of three, or perhaps because someone has written a poem or a song and this is better placed last, or for a range of other emergent reasons.

The key point here is that small groups of about three to five people work together to prepare a joint woven narrative which they feel comfortable sharing with a wider group. As facilitators, we find that participants often want to spend time in this part of the workshop and that we need to keep them flowing along. What we know - and what participants do not know, as they try to create a perfect métissage-is that we need to ensure sufficient space for the reading and dialogue that will follow. We give enough space so that relationships can deepen; however, we also encourage participants to be efficient in the interest of the greater purpose of our time together.

\section{Refining the process of sharing stories and creating conditions for listening}

When it comes time for each group to share their métissage, we determine the order of the groups by asking who would like to go first. Then, we offer three points for consideration. Firstly, based on an earlier insight from our Artistic Director colleague, Will Weigler, we speak to the aesthetic choice of whether to leave or not to leave much space between each person's narrative to give the effect of interrupting one another-just as our lives are often interrupted by others (Etmanski et al., 2013).

Secondly, as participants often feel the cultural urge to applaud after each reading, we do ask that they hold any applause until all participants have read their contributions. This allows the full stories to be expressed and heard and allows the applause to honour the whole rather than individual groups. This also minimizes the tendency to compare and compete, or set an expectation of performance accompanied by applause. Thirdly, we acknowledge that it is a true gift to receive another's story. We ask that people actively listen to one another's stories with a level of sacredness and respect.

Finally, in order to open people's ears and hearts to be better prepared to receive the stories, we have found it useful to invite participants to pause for a moment before the reading, feel grounded in their seats, and take three shared breaths. The importance of setting the stage in this way lies in enabling participants to really hear the stories that are shared and to honour 
the stories as gifts from the teller with the present moment awareness that can be cultivated from taking three intentionally deeper breaths.

\section{Refining the process of dialogue}

After the métissage is complete, we allow a pause for participants to absorb the stories by taking a moment of silence. We encourage participants to take in what they heard and feel how the stories have landed inside for them. As facilitators we are mindful of the energy in the room. Because personal details are sometimes disclosed through the telling, people may feel vulnerable, or deeply touched by hearing another's story. As such, we begin gently, softly, and do not move to a large group analytical conversation too quickly. We often invite participants to turn to the person next to them and share one thing that struck them or that they noticed. In this way, participants are able to gather their thoughts and engage in a more intimate dialogue which they might not do in the larger group immediately. We then bring the dialogue back to the full group. We debrief the conversation according to the theme of the session, based on participants' observations about what happened in the experience of writing, editing, weaving, sharing, and listening through métissage.

\section{Round 1: After Reading of Facilitators' Métissage:}

Pause (Allow a pause after reading, notice the shift in energy, then quietly engage).

Pair \& Share (We invite you to turn to the person next you and share one thing that struck you or that you noticed?)

Group Dialogue: (After pair \& share, engage in large group conversation asking overall: What happened? What did you notice? What came up for you; either personally or symbolically?)

Some deeper process questions that might be used:

1. What themes did you notice among the narratives?

2. Did you notice any anomalies?

3. What did you learn from these themes or anomalies?

4. How did the various stories resonate with you?

5. Did anything surprise you?

6. Did you notice any differences (e.g., based on gender or culture)?

7. Did anything confirm what you currently are thinking about [Workshop Topic]?

8. What did you learn about [Workshop Topic/Writing Prompt/Métissage itself]?

\section{Round 2: After Reading of Participants' Métissage:}

Group Dialogue: Revisit earlier questions if appropriate, e.g., What did you notice? What came up for you either personally or symbolically?

Some deeper process questions used:

1. Did you see yourself reflected in another's story?

2. What did you learn/ about métissage as a method or as a process of uncovering and coconstructing knowledge about self, others, and the world?

3. What was the difference between hearing the facilitators' story and telling your own story?

4. What does any of this tell us about [Workshop Topic]?

5. Might you apply what you learned about content or the process? If so, how?

Figure 1. Sample reflective questions 


\section{Recognizing the impact on listeners}

As described by Etmanski et al. (2013), listeners frequently report at least two (of many potential) categories of experience upon witnessing or participating in crafting a métissage. First, as story-tellers speak, listeners are often able to see themselves reflected in the stories. This can allow for greater self-knowledge in multiple ways. For example, people's experiences may be validated through the understanding that they are not alone, or, conversely, listeners might reframe their own experiences through hearing a different perspective on a similar topic. They may even gain some awareness about the hurtful effect their behaviour could have on others. In addition, stereotypes and assumptions often become dismantled as we learn more about people's life experiences (e.g., contesting preconceptions that social privilege precludes pain). People can feel greater compassion and empathy as the complexity of another person's life unfolds before them. In this way, the métissage, like other arts-based methods, moves from expressing individual stories to becoming "a means of conveying truths about the human condition" (Furman, 2006, p.138). These personal narratives are not didactic or necessarily intended to convey a particular message. Rather, as points of connection are made between the tellers and the audience, people can extract their own meaning and apply these truths in their own contexts (Etmanski et al., 2013).

\section{Closing the workshop}

Facilitators have different ways they like to close their sessions. After a rich dialogue that often leads to deepened relationships, we ask participants to speak one word or a short phrase into the space. This word can capture what the experience was like for them, or, time permitting, allow for a longer wrap up.

\section{Lessons Learned through Facilitating in Diverse Contexts}

The above section explains what we do and offers a little context for why we do it. In this section, we offer some key lessons we have learned through the grace of participants about: clarifying the process, working with emotions, and adjusting to the context.

\section{Clarifying the process}

Although we have experientially come to appreciate the power of métissage, as facilitators we also take great care to help participants understand the process upon which they are about to embark. As mentioned, we often reiterate that this is an invitation; they can choose how much they want to challenge themselves. We offer that we are each responsible for taking care of ourselves while at the same time considering how we might co-create brave spaces or spaces of grace, thereby extending that care to others. Sometimes we experience resistance from participants, especially if they do not feel that they fully understood what the process would entail. As such, we invite them to flow with the process or choose how they will participate, reiterating that being an observer can be a powerful role; assuring them we will revisit their insights and observations in the debrief. We also offer ideas for consideration to participants depending on what may arise. For example, to avoid a culture of one up-person-ship developing, we reiterate that each person brings unique and important stories and ways of telling. We 
encourage people to claim who they are and know that "everything belongs" (Rohr, 2013, p. 16). We frequently speak to the fact that we may choose to share different stories depending on who we are with, whether colleagues or strangers.

\section{Working with emotions as they emerge}

We recognize the power of arts-based practices to take people to deeper places inside themselves and, sometimes, rather quickly (Etmanski \& Bishop, 2017). Through enabling participants to speak their own stories and listen to others, participants can be moved to a profound level of feeling and connection. Depending on the person and the topic, the content shared may be difficult for some people and strong emotions can be evoked. In addition to stressing the need for people to take care of themselves, as well as their decision to keep their stories as light or deep as they would like, as facilitators we stay alert to how individuals may be feeling in the moment and the emotional tone of the whole group. Recognizing the possibility that tears may arise, when this happens, we respectfully support people in the moment, connecting the experience back to the purpose so that we also support the whole group in moving forward. We also follow up privately with an individual to check whether we can be of further support.

\section{Adjusting to the context}

We recognize that each group and context is unique, and that the process has elements of interruptions, diversity, unity, and messy reality. As a result, we are mindful to make adjustments to the process as it unfolds. Some adjustments may be related to timing (e.g., shortening the editing time to ensure a more fulsome group reflection at the end) or on the process itself (e.g., having actors perform stories if it wasn't deemed safe for people to share their own storiessee Etmanski et al, 2013).

As another example, Beth utilized métissage to present her research findings at a conference (Page, 2016). As the researcher, she wove together excerpts of data and participants' stories in response to the research question about what sustained leaders when navigating challenge. She invited conference attendees to read the excerpts. This approach served the desire to express the research narrators' own words, bring the findings to life, preserve the confidentiality of research participants, and allow different voices to represent the diversity of the research participants who took part in the study. Likewise, Cheryl and Kathy had a whole room of approximately 50 students each read their sections in turn, in an attempt to make space for all narratives within a short timeframe. We hope these examples encourage you to stay present to what is happening in your specific context and adapt as you feel inspired.

\section{Sharing Our Example}

Having offered insights on the theory and practice of métissage, in this final section we share an example of our own reflexive writing on the prompt: The Power of Métissage.

Brian: Prior to the workshop we talked about timing, should we have a careful space between our stories or quick succession, creating the feeling of piling on top of each other. These kinds of decisions, in the moment, had little meaning to me or understanding how they might play out in practice. Being invited to present a métissage workshop with two experienced 
colleagues was interesting for me because my academic and professional background was quite different, having little exposure to the arts.

Catherine: The idea of methodological risk-taking comes up in conversations with students from time to time. I recall that it also came up during my own doctoral defense when I suggested that we continue to allow lectures and PowerPoint presentations to dominate. If we want to address the complexity of today's challenges and bring our collective creative potential to the fore, we need to take more risks and make better use of alternative methods in the academy.

Beth: Through the window pane of métissage, the thoughts of individuals sharing their narrative, becomes an opportunity to share experiences, make meaning and concrete community. The prompt extends an invitation - an opportunity to convene on a topic of shared interest. What of the weaving process? Selecting a passage here, eliminating a passage there. Surfacing what most matters to share. Taking the individual passage and identifying three parts. Much like a beginning a middle and an end. Or is it an end a middle and a new beginning?

Cheryl: For me, métissage brings people and ideas together in a complex narrative. It weaves together the individual and the collective...messy, intricate, yet seemingly perfect. It can transform what is possible, demonstrating our connectedness and our individuality in one breath.

Catherine: A colleague once challenged the very idea that this was even a risk. She suggested that we know that arts-based and story-based practices work. We now have documented experience and lots of evidence of this. So, if we know it works, is it really a risk? Why do we continue to frame it as such?

Kathy: Lingering in my mind are stories, images, gestures, ah-has, and even sounds from many co-created métissage, it all belongs, like...

Brian: As we presented the workshop, each telling our stories, one on top of the other, mixed, and meaningful, I realized how I was not just a single player but like a tree in a forest, interacting with other trees. An individual among individuals, humbled by the stark contrast and juxtaposition of the other trees in the forest, their own stories like mine, familiar but distant. In this collective of sharing, I realized there was far more to gain.

Beth: The source can be self created through free writing or maybe the words and phrases are drawn from an existing source. The possibilities are endless. The creativity begins to be experienced and grows as individual passages are shared.

Catherine: Each time I hear a new métissage, I am delighted by the opportunity to learn more about you and about us together. Your joy. The ways you think and the way you are in the world. Your burdens to carry. Your humanity. And what these teach me about my own.

Cheryl: métissage is not bound simply by words. In métissage it all belongs: silence, phrases, gesture, imagery, and song. It has the potential to transcend dialect, language, class, and generation. For one moment, we all stand in the same field, diverse, yet connected by the thread of one prompt, one invitation. It is an invitation to reveal that which is unique to one and connected to many 


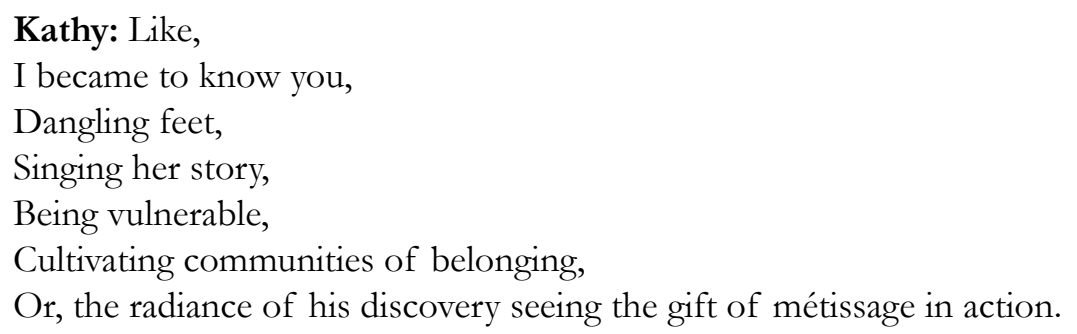

Brian: Once the workshop participants began their exercise of story telling, I was stunned by the sounds, stories, and song that emerged. It was as if the forest was coming alive as my focus shifted from my own story, and that of my colleagues, to the story of many. It was as if, in the chaos of variety and diversity an ecosystem of possibility was born.

Beth: The weaving, is much like a braid. Three parts, individually shared, now woven together. The work of the individual becomes the weave of the collective. Once individual, now shared. Once individual, now community, once alone, now together. In coming together, the power of the collective becomes visible. More meaning being created among participants now sharing a co-created experience. Through the windowpane of métissage, individual narratives weaving together a collective narrative. Community cultivated through the experience of coming together.

Kathy: A kaleidoscope of stories, images, gestures, ah-has, and sounds, all belonging, creating a new métissage within my mind. I came to know you. And realize through this process I also came to know us and me.

Cheryl: Métissage breathes life into possibilities, possibilities into connections, and connections into collective memories. Braiding story over story, métissage weaves magic and meaning with the stories that live in our bodies and our hearts. Métissage helps to remember the connectedness inherent in what it means to be alive. For me, that is power beyond measure.

\section{Closing Reflections}

In this article, we have offered a practical way to-as Hendry (2007) stated in the opening quote-allow networks "of relationships construct the narrative" while "disrupting categories of subject/object, time/space, past/present/ future, and body/mind/spirit" (p. 492). We hope readers who share an interest in forefronting the narrative experiences of the people with whom they work might feel encouraged by the practical strategies, lessons, and examples shared throughout this text. We also hope the theoretical framing of métissage offered at the outset enables readers to appreciate métissage as more than a simple tool. Just as scholars before us have opened the space for us to find our own individual and collective narratives in this work, we invite you to add a strand to the ever-expanding métissage by weaving your narrative together with ours. 


\section{About the Authors}

Kathy Bishop (corresponding author) is an associate professor and a program head for the Master's of Arts in Leadership at Royal Roads University in Victoria, British Columbia. Email: kathy.bishop@royalroads.ca

Brian Dominguez is a doctoral candidate at Royal Roads University.

Catherine Etmanski is a professor and director of the School of Leadership Studies at Royal Roads University.

Cheryl Heykoop is an assistant professor and a program head for the Master's of Arts in Leadership in the School of Leadership Studies at Royal Roads University.

Beth Page is an author, consultant, coach, educator, international speaker and Dream Catcher Consulting founder. Beth also teaches at Royal Roads University.

\section{References}

Adichie, C. N. (2009). The danger of a single story. TED Global. [Video File]. Retrieved from https://www.ted.com/talks/chimamanda_adichie_the_danger_of_a_single_story

Arao, B., \& Clemens, K. (2013). From safe spaces to brave spaces: A new way to frame dialogue around diversity and social justice. In L. M. Landreman (Ed.), The art of effective facilitation: Reflections from social justice educators (pp. 135-150). Sterling, VA: ACPA College Student Educators International/Stylus.

Bruner, J. (1991). The narrative construction of reality. Critical Inquiry, 18(1), 1-21.

Chambers, C., Donald, D., \& Hasebe-Ludt, E. (2002). Creating a curriculum of métissage. Educational Insights 7(2). Retrieved from http://ccfi.educ.ubc.ca/publication/insights/v07n02/ metissage/metiscript.html

Chambers, C., Hasebe-Ludt, E., Donald, D., Hurren, W., Leggo, C., \& Oberg, A. (2008). 12 Métissage: A research praxis. In Handbook of the arts in qualitative research: perspectives, methodologies, examples, and issues (pp. 142-155). Thousand Oaks, CA: Sage.

Chambers, C., Hasebe-Ludt, E., Leggo, C., \& Sinner, A. (Eds.) (2012). A heart of wisdom: Life writing as empathetic inquiry. New York, NY: Peter Lang.

Chawla, D., \& Rodriguez, A. (2011). Liminal traces: Storying, performing, and embodying postcoloniality. Rotterdam, Netherlands: Sense.

Clandinin, D. (2013). Engaging in narrative inquiry. Walnut Creek, CA: Left Coast Press.

Clandinin, D., \& Connelly, F. (2000). Narrative inquiry: Experience and story in qualitative research. San Francisco, CA: Jossey-Bass. 
Connelly, F., \& Clandinin, D. (1990). Stories of experience and narrative inquiry. Educational Researcher, 19(5), 2-14.

Davis-Manigaulte, J., Yorks, L., \& Kasl, E. (2006). Expressive ways of knowing and transformative learning. New Directions for Adult and Continuing Education, 109, 27-35.

Denzin, N. (1997) Interpretive ethnography: Ethnographic practices for the $21^{\text {st }}$ century. Thousand Oaks, CA: Sage.

Donald, D. (2012). Indigenous Métissage: a decolonizing research sensibility. International Journal of Qualitative Studies in Education, 25(5), 533-555.

Etmanski, C. (2014). Creating the learning space: Teaching arts-based research. In C. Etmanski, B. Hall, \& T. Dawson, (Eds.) Learning and teaching community-based research: Linking pedagogy to practice (pp. 265-284). Toronto, ON: University of Toronto.

Etmanski, C., \& Bishop, K. (2017). Creativity and action research. In Hilary Bradbury and Associates, Cooking with action research: Resources for self and community transformation, Volume 2 "How To" (pp. 81-94). Portland, OR: AR+.

Etmanski, C., Weigler, W., \& Wong Sneddon, G. (2013). Weaving tales of hope and challenge: Exploring diversity through narrative métissage. In D. E. Clover \& K. Sanford (Eds.), Artsbased education, research and community cultural development in the contemporary university: International perspectives (pp. 123-134). Manchester, UK: Manchester University.

Furman, R. (2006) Poetry as research: Advancing scholarship and the development of poetry therapy as a profession. Journal of Poetry Therapy: The Interdisciplinary Journal of Practice, Theory, Research and Education, 19(3), 133-145.

Hasebe-Ludt, E., Chambers, C., \& Leggo, C. (2009). Life writing and literary métissage as an ethos of our times. New York, NY: Peter Lang.

Hasebe-Ludt, E., Chambers, C., Leggo, C., \& Sinner, A. (2013). Life writing: Discerning truths dwelling in the heart of humanity. Retrieved from http://www.lifewriting.ca/metissage/

Hayes, S., \& York, K. (2007). Lessons from the lessons learned: Arts change the world when...New Directions for Adult and Continuing Education, 116, 89-98.

Hendry, P. (2007). The future of narrative. Qualitative Inquiry, 13 (4), 487-498.

Heron, J. (1992). Feeling and personhood: Psychology in another key. Thousand Oaks, CA: Sage.

Josselson, R. (1995). Imagining the real: Empathy, narrative, and the dialogic self. In R. Josselson \&

A. Lieblich (Eds.), Interpreting experience: The narrative study of lives (pp. 1-26). Thousand Oaks, CA: Sage.

Kelly, V. (2012). A Métis manifesto. In C. Chambers, E. Hasebe-Ludt, C. Leggo, \& A. Sinner (Eds.), A Heart of wisdom: Life writing as empathetic inquiry (pp. 363-368). New York, NY: Peter Lang.

Lowan-Trudeau, G. (2012). Methodological métissage: An interpretive Indigenous approach to environmental education research. Canadian Journal of Environmental Education, 17, 113-130.

Page, M. B. (2016). Leading with heart: Beyond the heroic myth of leadership (doctoral dissertation). University of Victoria, Victoria, BC. Retrieved from https://dspace.library.uvic.ca// handle/1828/7092

Polkinghorne, D. (1995). Narrative configuration in qualitative analysis. International Journal of Qualitative Studies 8, 5-23.

Rohr, R. (2013). Everything belongs. New York, NY: Crossroads. 
Simpkins, S. (2012). Narrative métissage: Crafting empathy and understanding of self/other (doctoral dissertation). University of Victoria, Victoria, BC. Retrieved from https://dspace.library.uvic. $\mathrm{ca} /$ handle/1828/3961

Stauffer, S. (2014). Narrative inquiry and the uses of narrative in music education research. In C. Conway (Ed.), The Oxford handbook of qualitative research in American music education (pp. 163185). New York, NY: Oxford University.

Wagamese, R. (2016). Embers: One Ojibway's meditations. Madeira Park, BC: Douglas and McIntyre. 